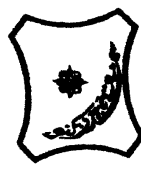

Bayero Journal of Pure and Applied Sciences, 10(1): 108 - 114

Received: April, 2017

Accepted: June, 2017

ISSN $2006-6996$

\title{
ANTI-DIABETIC EFFECT OF ETHANOL LEAF EXTRACT OF Combretum micranthum ON BLOOD GLUCOSE AND OXIDATIVE STRESS BIOMARKERS ON ALLOXAN INDUCED DIABETIC IN WISTAR RATS
}

\author{
${ }^{*} 1$ Tanko, Y. , ${ }^{1}$ Suleiman, I., ${ }^{1}$ Jimoh, A., ${ }^{2}$ Musa, S. A., ${ }^{3}$ Mohammed, K.A., ${ }^{4}$ Salisu, A.I. and \\ ${ }^{5}$ Yusuf, $\mathbf{R}$. \\ ${ }^{1}$ Department of Human Physiology, Ahmadu Bello University, Zaria, Nigeria \\ ${ }^{1}$ Department of Human Anatomy, Ahmadu Bello University, Zaria, Nigeria \\ ${ }^{3}$ Department of Human Physiology, Kaduna State University, Nigeria \\ ${ }^{4}$ Department of Human Physiology, Bayero University, Kano, Nigeria \\ ${ }^{5}$ Department of Chemical Pathology, Ahmadu Bello University, Zaria, Nigeria \\ *Corresponding author: yusuftanko@abu.edu.ng Tel: +2348037054274
}

\begin{abstract}
This research was aimed to investigate the anti-diabetic effects of ethanol leaf extract of Combretum micranthum on blood glucose levels and oxidative stress biomarkers such as malondaldehyde, superoxide dismutase, catalase and glutathione peroxidase on alloxan induced Diabetes in Wistar rats. Diabetes was induced using alloxan (150 $\mathrm{mg} / \mathrm{kg}$ i.p). The rats were grouped into five groups of five rats each. Group 1 served as the diabetic control, Group 2 received $2 \mathrm{mg} / \mathrm{kg}$ glibenclamide, while Groups 3, 4 and 5 were orally administered 100, 200 and $400 \mathrm{mg} / \mathrm{kg}$ body weight of ethanol leaf extract of Combretum micranthum for a period of 4 weeks, respectively. Blood were collected from the tail artery and the serum was used to determine the oxidative stress biomarkers (malondaldehyde, superoxide dismutase, catalase and glutathione peroxidase). There was a significant $(p<0.05)$ decrease in the blood glucose when compared with the diabetic control. Also there was a significant $(p<0.05)$ decrease in the oxidative stress biomarkers when compared with the diabetic control. The preliminary phytochemical screening of the of the extracts revealed the presence of tannins flavonoids, cardiac glycosides, alkaloids, terpenoids and resins. The $L D_{50}$ was greater than $5000 \mathrm{mg} / \mathrm{kg}$ orally. In conclusion Combretum micranthum reduce blood glucose levels, reactive oxygen free radicals and improved the activities of the antioxidant enzymes.
\end{abstract}

Keywords: Diabetic, Combretum micranthum, Blood glucose, Oxidative stress, Phytochemicals

\section{INTRODUCTION}

Diabetes is widely recognized as one of the leading causes of death and disability worldwide (ADA,2010) The prevalence of diabetes will rise from $6 \%$ to over $10 \%$ in the next decade (Rosen et al., 2001) . In 2000, the World Health Organization (WHO) recorded a total of 171 million people for all age groups worldwide (2.8\% of the global population) who have diabetes, and the numbers are expected to rise to 366 million (4.4\% of the global population) by 2030.( Wild et al., 2004)

Diabetes is a group of metabolic diseases characterized by high levels of blood sugar (hyperglycemia). It results from defects in insulin production and/or insulin action, and impaired function in the metabolism of carbohydrates, lipids and proteins which leads to long term health complications (Oktayoglu et al., 2010; ADA 2010). In diabetic patients, long-term damage, dysfunction, and failure of different organs, especially the eyes (diabetic retinopathy), kidneys (diabetic nephropathy), nerves (diabetic neuropathy), heart (myocardial infarction), and blood vessels (atherosclerosis) are related to uncontrolled hyperglycemia(ADA,2010; Chintan et al.,2011).

Oxidative stress results from increased reactive oxygen species(ROS) and/or reactive nitrogen species (RNS).( Joseph et al., 2003) Examples of ROS include charged species such as superoxide and the hydroxyl radical, and uncharged species such as hydrogen peroxide and singlet oxygen. The possible sources of oxidative stress in diabetes might include auto-oxidation of glucose, shifts in redox balances, decreased tissue concentrations of low molecular weight antioxidants, such as reduced glutathione (GSH) and vitamin $\mathrm{E}$, and impaired activities of antioxidant defense enzymes such as superoxide dismutase (SOD) and catalase (CAT).( Haskins et al., 2003). ROS generated by high glucose is causally linked to elevated glucose and other metabolic abnormalities important to the development of diabetic complications. However, the exact mechanism by which oxidative stress may contribute to the development of diabetic complications is undetermined.( Kowluru and Chan 2007).The aetiology of oxidative stress in diabetes arises from 
a variety of mechanisms such as excessive oxygen radical production from auto-oxidation of glucose, glycated proteins, and glycation of antioxidative enzymes, which limit their capacity to detoxify oxygen radicals. (Wolff 1993) Giugliano,1995;). In addition to these mechanisms, two others have been suggested as being responsible for the generation of oxygen radicals in diabetes. Jain(1989) reported that high glucose levels could stimulate cytochrome P450-like activity by excessive nicotinamide adenine dinucleotide phosphateoxidase (NADPH) produced by glucose metabolism. Furthermore, ketosis, a hallmark of T1DM in particular, could increase oxygen radical production in diabetic patients. (Jain 1998)

Combretum micranthum is popularly known as Sansami in the Hausa culture of Nigeria. It is used traditionally in Senegal and Mali for fatigue, liver ailments, headache, convalenscence, diabetes, blood disease, weight loss, cancer, sleep disorders, and it is especially used for fasting by Mourides in Senegal. It is one of the plants of power in Nigerian medicine and is used to treat liver disorders. Kinkeliba means "health tree"and the French import kinkeliba and call it "tisane de longue vie" or infusion of life (Schmidt et al., 2008). The branches of the tree are quite strong, and are a useful material for building tools, beds, tool handles, etc. A tea produced by steeping the leaves in boiling water is a traditional tonic drink in tropical savannah countries. The aim of this research was to investigate the anti-diabetic effect of ethanol leaves extract of Combretum micranthum on blood glucose levels and oxidative stress biomarkers on alloxan induced diabetic rats.

\section{MATERIALS AND METHODS}

\section{Collection of Plant Materials}

Fresh leaves of Combretum micranthum were collected from Hunkuyi town, Kudan Local Government Area of Kaduna State, Nigeria in January, 2016. The plant was authenticated at the Herbarium Section of the Department of Biological Sciences, Ahmadu Bello University, Zaria, Kaduna state, Nigeria. A voucher specimen (No 1520) has been deposited for future reference.

\section{Chemicals / drugs used}

Glibenclamide and alloxan were purchased from Sigma chemical Company St. Louis U.S.A..

\section{Preparation of Extract}

Combretum micranthum leave were air dried under shade for twenty one days and then size-reduced into powder with a pestle and mortar. About $150 \mathrm{~g}$ of the powdered leaves was macerated with $250 \mathrm{ml}$ ethanol for 72 hours with occasional shaking. The extract was concentrated in vacuo affording a yield of $18.4 \% . \mathrm{w} / \mathrm{w}$ and subsequently referred to as ethanol leaf extract of Combretum micranthum .

\section{Preliminary Phytochemical Screening}

The screening was carried out in accordance with the standard protocol as described by Trease and Evans (1983).

\section{Acute toxicity study}

The lethal dose $\left(L D_{50}\right)$ of the plant extract was determined by the method of Lorke (1983) using 12 mice. In the first phase, mice were divided into 3 groups of 3 mice each and were treated with the extract at doses of 10,100 and $1000 \mathrm{mg} / \mathrm{kg}$ body weight orally. They were observed for 24 hours for signs of toxicity and death. In the second phase, 3 groups containing one mouse each were injected with four more specific doses of the extract administered orally. The median Lethal dose $\left(L_{50}\right)$ was determined as the geometric mean of the highest non lethal dose and the lowest lethal dose of which there is $1 / 1$ and $0 / 1$ survival.

\section{Experimental animals}

Twenty five (25) Wistar rats of both sexes weighing 120-150 g were obtained from the Animal House of the Department of Human Physiology, Ahmadu Bello University, Zaria, Nigeria. The rats were maintained on standard laboratory animal feed and water ad libitum, and housed in polypropylene cages at room temperature throughout the study. The animals were maintained on standard small animal feeds (Excel feed, Ilorin, Nigeria).

\section{Induction of Diabetes}

Wistar rats were fasted for about 16-18 h, after which hyperglycamia was induced by a single intraperitoneal injection of Alloxan monohydrate dissolved in $0.9 \%$ cold normal saline solution at a dose of $150 \mathrm{mg} / \mathrm{kg}$ body weight (Katsumata et al., 1999). Alloxan produces fatal hypoglycaemia and to prevent this, the rats were treated with $20 \%$ glucose solution orally for 6 hours. After which they were placed on 5\% glucose solution for 24 hours (Dhandapani et al., 2002). Blood was collected from the tail vein of the rats after 72 hours of Alloxan injection. The rats having fasting blood glucose level greater than or equal to $200 \mathrm{mg} / \mathrm{dl}$ were selected for the study.

\section{Experimental Design}

A total of twenty five (25) Wistar rats were used; the animals were randomly divided into five groups of five rats each as follows:

Group 1: Diabetic control administered Distilled water $5 \mathrm{mg} / \mathrm{kg}$ body weight for 4 weeks orally

Group 2: Diabetic administered glibenclamide 2 $\mathrm{mg} / \mathrm{kg}$ body weight for 4 weeks orally

Group 3: Diabetic administered $100 \mathrm{mg} / \mathrm{kg}$ body weight ethanol leaf extract of Combretum micranthum for 4 weeks orally. Group 4: Diabetic administered 200 $\mathrm{mg} / \mathrm{kg}$ body weight ethanol leaf extract of Combretum micranthum for 4 weeks orally

Group 5: Diabetic administered $400 \mathrm{mg} / \mathrm{kg}$ body weight ethanol leaf extract of Combretum micranthum for 4 weeks orally

\section{Determination of Fasting blood glucose levels}

Fasting blood glucose levels were determined by using the glucose oxidase method (Trinder, 1969) with ONE TOUCH BASIC ${ }^{\circledR} \quad$ Digital Glucometer (LIFESCAN, Inc 2001 ) and results were reported as $\mathrm{mg} / \mathrm{dL}$ (Rheney and Kirk, 2000). Blood glucose level was determined by collection of blood sample from the tail artery. Rat with blood glucose levels $200 \mathrm{mg} / \mathrm{dL}$ and above were considered for the study. 


\section{Blood Sample Collection and Serum Preparation} After the treatment all animals were sacrificed using light chloroform and $5 \mathrm{~mL}$ of blood sample were collected into specimen bottles and allowed to clot and separated by centrifugation at 3,000 $g$ for 10 minutes using Centrifuge Hitachi (Universal 32, Made in Germany). The supernatant obtained were used for the determination of lipid profile and liver enzymes.

\section{Determination of oxidative stress Biomarkers:}

\section{Lipid peroxidation biomarker (MDA)}

Lipid peroxidation can be evaluated by the thiobarbituric acid reactive substances method (Gallou et al., 1993). Serum malondialdehyde (MDA) levels were measured by the double heating method of Draper and Hadley (1990) using Malondialdehyde Assay kits from Northwest Life Sciences Specialties (NWLSS ${ }^{T M}$, product NWK-MDA01). Butylated hydroxytoluene (BHT) in methanol reagent was used as the control. The method is based on the spectrophotometric measurement of the purple color generated by the reaction of thiobarbituric acid (TBA) with MDA at $532 \mathrm{~nm}$. The MDA formed will therefore be quantified using an extinction coefficient of $1.56 \mathrm{x}$ $10^{5} / \mathrm{mole} / \mathrm{cm}$ (Yagi, 1987). The amount of MDA formed in the control samples is subtracted from the amount in the experimental samples to obtain the amount of MDA in each sample. Since absorbance is directly proportional to the concentration, thus; concentration of MDA in each sample = Absorbance in sample Absorbance in control $\times 10^{5} \mathrm{nmol} / \mathrm{ml} \div 1.56 \times 10^{5}$ $\mathrm{M}^{-1} \mathrm{CM}^{1}$

\section{Superoxide dismutase activity}

Superoxide dismutase (SOD) activities were measured by the method of Misra and Fridovich (1972). Serum $(0.5 \mathrm{~mL})$ was diluted to $1.0 \mathrm{~mL}$ with distilled water, and $250 \mu \mathrm{l}$ of chilled ethanol and $150 \mu \mathrm{l}$ of chilled chloroform were added. The mixture were shaken and centrifuged. The supernatant were used for the assay of enzyme activity. To $1.2 \mathrm{~mL}$ of the supernatant were added 1.5 $\mathrm{mL}$ of $0.1 \mathrm{~mol} / \mathrm{L}$ carbonate-bicarbonate buffer, $\mathrm{pH} 10.2$, containing $0.2 \mathrm{mmol} / \mathrm{L}$ EDTA. The contents were mixed, and the reaction as initiated by adding $200 \mu \mathrm{l}$ of epinephrine ( $\mathrm{pH} 3.0,3 \mathrm{mmol} / \mathrm{L})$ to the buffered reaction mixture. The changes in optical density per minute were measured at $470 \mathrm{~nm}$.

\section{Catalase activity}

Catalase (CAT) activities were assayed by the method of Sinha (1972). $0.1 \mathrm{~mL}$ of serum and $1.5 \mathrm{~mL}$ of phosphate buffer were added. To this, $0.4 \mathrm{~mL}$ of hydrogen peroxide was added and the reactions were arrested after 30 and 60 second by the addition of $2.0 \mathrm{~mL}$ dichromate acetic acid reagent. A control was also carried out simultaneously. All the tubes were heated in a boiling water bath for exactly $10 \mathrm{~min}$, cooled and absorbance read at $620 \mathrm{~nm}$. Standards in the range of 2-10 Mmoles were taken and processed as the test. The activities of catalase were expressed as $\mu$ moles of hydrogen peroxide consumed/min/mg of protein (unit per milligram of protein).

\section{Glutathione Peroxidase}

The NWLSS ${ }^{\text {TM }}$ Glutathion peroxidase Assay kit was used which is an adaptation of the method of Paglia and Valentine (1967). Glutathione peroxidase catalyses the reduction of hydrogen peroxide $\left(\mathrm{H}_{2} \mathrm{O}_{2}\right)$, oxidizing reduced glutathione (GSH) to form oxidized glutathione (GSSG). GSSG was then reduced by glutathione reductase (GR) and $\beta$-nicotinamide adenine dinucleotide phosphate (NADPH) forming $\mathrm{NADP}^{+}$(resulting in decrease absorbance at $340 \mathrm{~nm}$ ) and recycling the GSH. Since GPx is limiting, the decrease in absorbance at $340 \mathrm{~nm}$ is directly proportional to the GPx concentration. The absorbance was read at 1,2 and 3 minutes against reagent blank. The absorbance for blank was subtracted from the sample reading to give the corrected value. Thus, GPx activity was calculated using 8.412 as the extinction coefficient:

$\mathrm{GPx}(\mathrm{U} / \mathrm{L})=8.412 \times \Delta \mathrm{A} 340 / \mathrm{min}$

$\mathrm{U} / \mathrm{L}=$ unit activity per liter

$\Delta$ A $340 / \mathrm{min}=$ change in absorbance at 340 per minute.

\section{Statistical Analysis}

Data obtained from each group were expressed as mean \pm SEM. The data were statistically analyzed using (ANOVA). All statistical analysis was evaluated using SPSS version 17.0 software and Microsoft Excel (2007). The values of $P \leq 0.05$ were considered as significant.

\section{RESULTS}

The preliminary phytochemical screening of the extract revealed the presences of tannin, flavonoid, alkaloid cardiac glycosides resin and terpenoids as shown in table 1

Table 1: Preliminary phytochemical screening of ethanol leaves extract of Combretum micranthum

\begin{tabular}{|l|l|}
\hline Constituents & Remark \\
\hline Tannins & + \\
\hline Saponins & - \\
\hline Flavonoids & + \\
\hline Alkaloids & + \\
\hline Cardiac glycosides & + \\
\hline Resins & + \\
\hline Terpenoids & + \\
\hline Carbohydrates & - \\
\hline Anthraquinone & - \\
\hline
\end{tabular}

Note: + Present, - Absent, Acute toxicity study (LD $\left.{ }_{50}\right)$ 
Bajopas Volume 10 Number 1 June, 2017

Table 2: The Percentage Mortality of the Different Doses of ethanol leaves extract of Combretum micranthum Administered orally to Wistar Rats during the First Phase of the Acute Toxicity Study.

\begin{tabular}{cccc}
\hline Group $(\mathrm{n}=3)$ & Treatment & Mortality & $\%$ Mortality \\
\hline 1 & $10 \mathrm{mg} / \mathrm{kg}$ extract & $0 / 3$ & 0.00 \\
2 & $100 \mathrm{mg} / \mathrm{kg}$ extract & $0 / 3$ & 0.00 \\
3 & $1000 \mathrm{mg} / \mathrm{kg}$ extract & $0 / 3$ & 0.00 \\
\hline
\end{tabular}

Table 3 : The Percentage Mortality of the Different Doses of ethanol leaves extract of Combretum micranthum Administered orally to Wistar Rats during the Second Phase of the Acute Toxicity Study.

\begin{tabular}{cccc}
\hline $\operatorname{Group}(\mathrm{n}=3)$ & Treatment & Mortality & $\%$ Mortality \\
\hline 2 & $1600 \mathrm{mg} / \mathrm{kg}$ extract & $0 / 1$ & 0.00 \\
3 & $2900 \mathrm{mg} / \mathrm{kg}$ extract & $0 / 1$ & 0.00 \\
4 & $5000 \mathrm{mg} / \mathrm{kg}$ extract & $0 / 1$ & 0.00 \\
\hline
\end{tabular}

The $\mathrm{LD}_{50}$ were then calculated as the square root of the product of the lowest lethal dose and highest non-lethal dose i.e. the geometric mean of the consecutive doses for which 0 and $100 \%$ survival rates were recorded in the second phase. The median lethal dose $\left(L D_{50}\right)$ in rats was calculated to be greater than $5000 \mathrm{mg} / \mathrm{kg}$ body weight orally as shown in table 3 . The sign of toxicity were first noticed after 8-10 hours of extract administration. There was decreased locomotor activity, decreased feed intake, and prostration after 8 hours of extract administration.

\section{Effect ethanol leaves extract of Combretum} micranthum On Blood Glucose Levels:

There was a significant decrease $(p<0.05)$ in the blood glucose levels of the diabetic groups treated with the extract after one week of treatment in the group administered $400 \mathrm{mg} / \mathrm{kg}$ only when compared to diabetic control untreated as shown in table 4 . However, after 23 and 4 weeks of treatment with the two doses (200 and $400 \mathrm{mg} / \mathrm{kg}$ ) of the extract shows a significant decrease $(p<0.05)$ in the blood glucose levels as compared to control. Furthermore, as regards to the standard drug (Glibenclamide $2 \mathrm{mg} / \mathrm{kg}$ ) as compared to diabetic control there was a significant decrease in the blood glucose levels as shown in table 4.

Effect of ethanol leaves extract of Combretum micranthum on Oxidative Stress Biomarkers:

When compared with the diabetic control, there was a significant decrease $(p<0.05)$ in the serum malondialdehyde level in the groups administered the three doses of extract respectively. Also in relation to the standard drug as compared to control, there was also a significant decrease $(p<0.05)$. As regards to the superoxide dismutase (SOD) concentration at the tested doses (100 200 and $400 \mathrm{mg} / \mathrm{kg}$ ) of the extract the level of the SOD increased significantly $(p<0.05)$ as compared with the control. Furthermore, the concentrations of catalase (CAT) and glutathione peroxidase (GPx) there levels increased significantly increased $(p<0.05)$ as compared with the control as shown in table 5. 
Bajopas Volume 10 Number 1 June, 2017

Table: 4 Effect of Ethanol Leaves Extract of Combretum Micranthum on Blood Glucose Levels (Mg/dL) on Alloxan Induced Diabetic Wistar Rats

\begin{tabular}{|c|c|c|c|c|c|}
\hline Groups/Treatments & Week 0 & Week 1 & Week 2 & Week 3 & Week 4 \\
\hline $\begin{array}{l}\text { Group I } \\
\text { (Diabetic untreated) }\end{array}$ & $292.0 \pm 0.92$ & $290.10 \pm 1.23$ & $288.20 \pm 1.32$ & $290.0 \pm 0.41$ & $291.60 \pm 1.18$ \\
\hline $\begin{array}{l}\text { Group II } \\
\text { (2mg/kg Glibenclamide) }\end{array}$ & $301.0 \pm 2.02$ & $252.2 \pm 0.11^{\mathrm{ns}}$ & $209.30 \pm 0.14^{a}$ & $189.1 \pm 0.64^{a}$ & $163.40 \pm 1.20^{\mathrm{a}}$ \\
\hline $\begin{array}{l}\text { Group III } \\
\text { (Combretum micranthum } \\
100 \text { mg.kg ) }\end{array}$ & $304.30 \pm 0.62$ & $271.3 \pm 0.22^{\mathrm{ns}}$ & $224.20 \pm 1.23^{n s}$ & $202.00 \pm 1.27^{n s}$ & $184.20 \pm 1.03^{a}$ \\
\hline $\begin{array}{l}\text { Group IV } \\
\text { (Combretum micranthum } \\
200 \mathrm{mg} / \mathrm{kg} \text { ) }\end{array}$ & $298.0 \pm 1.02$ & $242.0 \pm 2.12^{\mathrm{ns}}$ & $206.80 \pm 1.53^{a}$ & $201.2 \pm 2.00^{a}$ & $176.20 \pm 0.12^{a}$ \\
\hline $\begin{array}{l}\text { Group V } \\
\text { (Combretum micranthum } \\
400 \mathrm{mg} / \mathrm{kg} \text { ) }\end{array}$ & $292.2 \pm 2.01$ & $223.0 \pm 1.12^{a}$ & $213.00 \pm 1.07^{a}$ & $215.40 \pm 1.14^{a}$ & $156.0 \pm 0.31^{a}$ \\
\hline
\end{tabular}

Table 5: Effect of Ethanol Leaves Extract Of Combretum Micranthum on Oxidative Stress Biomarkers on Alloxan Induced Diabetic Wistar Rats

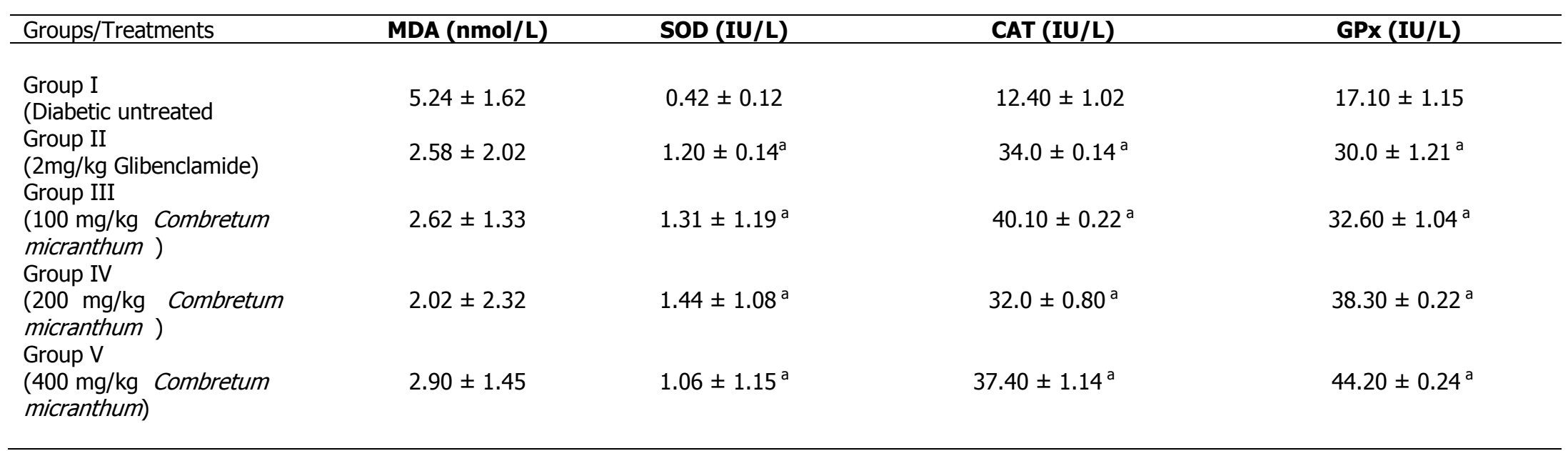

Values are expressed as mean $\pm \mathrm{SEM} ; \mathrm{n}=5$. ${ }^{\text {a: }}$ Value considered statistically significant when compared with control group ( $\left.p \leq 0.05\right) ;{ }^{\text {ns }}$ Value considered statistically significant when compared with control group.

112 


\section{DISCUSSION}

Alloxan- induced diabetes is characterized by hyperglycaemia, severe body weight loss, polydipsia, polyphagia and polyuria. Management of diabetes with agents devoid of any side effects is still a challenge to the medical system. This has led to an increase in the demand for natural products with antihyperglycemic activity and fewer side effects. Plants may act on blood glucose through different mechanisms, some of them may have insulin-like substances and some may inhibit insulinase activity (Bopanna et al., 1997. Administration of the ethanol extract of Combretum micranthum, there was a significant decreased $(p<0.05)$ in the blood glucose levels of the diabetic groups treated with the extract after one week of treatment in the group administered $400 \mathrm{mg} / \mathrm{kg}$ only when compared to diabetic control untreated as shown in table 4. However, after 2, 3 and 4 weeks of treatment with the two doses ( 200 and $400 \mathrm{mg} / \mathrm{kg}$ ) of the extract shows a significant decrease $(p<0.05)$ in the blood glucose levels as compared to control. However, as regards to the standard drug (Glibenclamide $2 \mathrm{mg} / \mathrm{kg}$ ) as compared to diabetic control there was a significant decreased $(p<0.05)$ in the blood glucose levels as shown in table 4. The activity of the ethanol extract of Combretum micranthum might be due to its secondary metabolites' present as revealed by the preliminary phytochemical screening such as flavonoid which has been reporter to have anti-diabetic potential. Some plants are involved in the stimulation of cells to produce more insulin (Chang and Johnson, 1980 and Collier et al., 1987) and others may increase cells in the pancreas by activating regeneration of pancreatic cells (Chakravarthy et al., 1980).

The results of the oxidative stress biomarkers such as malondialdehyde, superoxide dismutase, catalase and gluthathione peroxidase significantly increased when administered the ethanol extract of Combretum micranthum at the doses of 100, 200 and $400 \mathrm{mg} / \mathrm{kg}$ respectively, after 4 weeks. The results of our findings revealed a significant increased in the levels of superoxide dismutase, catalase and glutathione peroxidase as compared to diabetic control as shown in

\section{REFERENCES}

American Diabetes Association (2010) Diagnosis and classification of diabetes mellitus. J Diabetes Care. ;33:S62-9.

Bernabucci, U., Ronchi, B., Lacetera, N. and Nardone, A. (2002). Markers of Oxidative Status in Plasma and Erythrocytes of Transition Dairy Cows During Hot Season. J. Dairy Science, 85:21732179.

Bloch-Damti, A. and Bashan, N. (2005). Proposed mechanisms for the induction of insulin resistance by oxidative stress. Antioxid. Redox Signaling, 7: 1553-1567.

Bopanna K.N. Bopanna, J. Kannan, S. Gadgil, R. Balaraman, S.P. Rathod (1997)Antidiabetic and table 5. Superoxide dismutase (SOD) serves as the first line of defence against the deleterious effect of ROS. The function of intracellular SOD is to scavenge superoxide $\left(\mathrm{O}_{2}^{-}\right)$produced by cellular metabolism, and catalyse dismutation of superoxide to oxygen $\left(\mathrm{O}_{2}\right)$ and hydrogen peroxide $\left(\mathrm{H}_{2} \mathrm{O}_{2}\right.$ ) ( Bernabucci et al., 2002; Das, 2011). The increased dismutation of $\mathrm{O}_{2}^{-}$by SOD leads to increase in production of $\mathrm{H}_{2} \mathrm{O}_{2}$, which is further detoxified by CAT and GPx to $\mathrm{H}_{2} \mathrm{O}$ and $\mathrm{O}_{2}$ (Das, 2011). According to literatures, there are various studies reporting that diabetic subjects tend to have more oxidative internal environments than healthy normal subjects ( Phillips et al., 2004 ; Bloch-Damti and Basham, 2005). However, treatment with the ethanol extract of Combretum micranthum at the doses of 100 , 200 and $400 \mathrm{mg} / \mathrm{kg}$, produced significantly $(\mathrm{p}<0.05)$ increased SOD, catalase and GPx levels as compared with the diabetic control demonstrating the ability of extract of Combretum micranthum to reduce oxidative stress in diabetic rats. This might be due to the antioxidant properties of the extract such as the secondary metabolites that increased the activities of superoxide dismutase catalase and glutathione peroxidase observed after administration of ethanol extract of Combretum micranthum .Rats treated with the extract showed decreased lipid peroxidation (MDA) when compared to control as shown in table 5 . This is associated with an increased activity of SOD CAT and GPx respectively as shown in table 5 . This means that the extract can reduce reactive oxygen free radicals and improve the activities of the antioxidant enzymes.

\section{CONTRIBUTION OF AUTHORS}

This work was carried out in collaboration between all authors. Authors YT designed the study, wrote the protocol, IS and SAM wrote the first draft of the manuscript. Authors KAM and AIS managed the literature search; Author RY managed the statistical analysis of the study. Author AM managed the experimental process. All authors read and approved the final manuscript

\section{Conflict of Interests}

Authors have declared that no conflict of interests exists.

antihyperglycemic effects of Neem seed kernel powder alloxan diabetic rabbits. Indian $\mathrm{J}$. Pharmacol., 29 , pp. 162-167

Chakravarthy B.K. Chakravarthy, S. Gupta, S.S. Gambhir, K.D. Gode(1980) Pancreatic beta cell regeneration a novel antidiabetic mechanism of Petercarpus marsupium Indian J. Pharmacol., 12 , pp. $123-128$

Chang MW and Johnson M.A (1980 ) Effect of garlic on carbohydrate metabolism and lipid synthesis in rats J. Nutr., 110, pp. 931-936

Chintan AP, Nimish LP, Nayana B, Bhavna M, Mahendra G, Hardik T(2011). Cardiovascular complication of diabetes mellitus. J Appl Pharm Sci. ;4:1-6. 
Collier E. Collier, A. Watkinson, C.F. Cleland, J. Roth(1987) Partial purification and characterization of insulin like material from spinach and Lemna gibba G3 J. Boil. Chem., 262 , pp. 6237-6238

Draper, H. H. and Hadley,M. (1990). Malondialdehyde determination as index of lipid peroxidation. Methods in Enzymology, 186: 421-431.

Das, A. (2011). Heat stress-induced hepatotoxicity and its prevention by resveratrol in rats. Toxicology Mechanisms and Methods, 2(5): 393-399.

Dhandapani S, Ramasamy, SV, Rajagopal, S Namasivayam, N( 2002). Hypolipidemic effect of Cuminum cyminum L. on alloxan-induced diabetic rats. Pharmacol. Res, 46 (3): 251-255.

Gallou, G., Ruelland, A., Legras, B., Mangendre, D., Allannic, H. and Cloarec, L. (1993).

Plasma malondialdehyde in type I and type II diabetic patients. Clinica Chimica Acta. 214(2): 227234.

Giugliano D, Ceriello A, Paolisso G(1995). Diabetes mellitus, hypertension and cardiovascular diseases: which role for oxidative stress? Metabolism. ;44:363-8.

Haskins K, Bradley B, Powers K.(2003) Oxidative stress in type 1 diabetes. Ann NY Acad Sci. ;1005:43-54.

Jain SK.(1989) Hyperglycemia can cause membrane lipid peroxidation and osmotic fragility in human red blood cells. $J$ Biol Chem. ;264:21340-5.

Jain SK, Kannan K, Lim G.(1998) Ketosis (acetoacetate) can generate oxygen radicals and cause increased lipid peroxidation and growth inhibition in human endothelial cells. Free Radic Biol Med. ;25:1083-8.

Johansen JS, Harris AK, Rychly DJ, Ergul A.(2005) Oxidative stress and the use of antioxidants in diabetes: linking basic science to clinical practice. Cardiovasc Diabet ; 4:5-8

Joseph LE, Ira DG, Betty AM, Gerold MG(2003). Are oxidative stress activated signaling pathways mediators of insulin resistance and cell dysfunction? Diabetes. 2003;52:1-8.

Katsumata, KY, Katsumata, TO and Katsumata, $T(1999)$. Potentiating effects of diabetes combined usage of three sulfonylurea drugs on the occurrence of alloxan-induced in rats. Horm Metab Res, 25: 125-126

Kowluru RA, Chan PS.(2007) Oxidative stress and diabetic retinopathy. Exp Diabetes Res. ;4:43603.
Lorkes D. (1983). A new approach to practical acute toxicity testing. Advances in toxicology, 54:275-287.

Misra H.P. and Fridovich I. (1972) The role of the superoxide anion in the autooxidation of epinephrine and simple assay for superoxide dismutase, Journal of Biology and Chemistry, 247: 3170-3175.

Oktayoglu GS, Basaraner $\mathrm{H}$, Yanardag R, Bolkent S.(2009) The effects of combined treatment of antioxidants on the liver injury in STZ diabetic rats. Diges Dis Sci. ;54:538-46.]

Paglia D.E. and Valentine W.N. (1976). Studies on the quantitative and qualitative characterization of erythrocytes glutathione peroxidase, Journal of Laboratory and Clinical Medicine, 70: 158-169.

Phillips, M., Cataneo., R. N., Cheema, T. and Greenberg, J. (2004). Increased breath biomarkers of oxidative stress in diabetes mellitus. Clin Chim Acta, 344: 189-94.

Rheney, C.C., and Kirk, K. K. (2000). Performance of three blood glucose meters. Annals of Pharmacotherapy, 34 (3): 317-321.

Rice EC, Miller N, Paganaga G. Antioxidant properties of phenolic compounds. Tre Pla Sci. 1997;2:1529

Sinha, K. A. (1972). Colorimetric assay of catalase. Analytical Biochemistry, 47: 389-394.

Trease, G.E., Evans, M.C. (1983): Textbook of pharmacognosy. $12^{\text {th }}$ edition Ballieke Tindall. London. pp 343-383.

Trinder, P. (1969). Annals of Clinical Biochemistry: 6:24: Quoted in Cheesbrough, M. (1992) Medical Laboratory Manual for Tropical Countries. Vol. 1 (2nd Edition). ELBS, Cambridge. 527-545.

Valko M, Leibfritz D, Moncol J, Cronin MTD, Mazur M, Telser $J(2007)$. Free radicals and antioxidants in normal physiological functions and human disease. Int J Biochem Cell Biol. 2007;39:4484.

Wild SH, Roglic G, Green A, Sicree R, King H(2004) Global prevalence of diabetes: estimates for the year 2000 and projections for 2030. Diabetes Care. 2004;27:1047-53.

Wolff SP(1993). Diabetes mellitus and free radicals: free radicals, transition metals and oxidative stress in the aetiology of diabetes mellitus and complications. Br Med Bull. ;49:642.

Yagi, H., Matsumoto, M., Kunimoto, K., Kawaguchi, J., Makino, S. and Harada, M. (1987).

Analysis of the roles of CD4+ T cells in autoimmune diabetes of NOD mice using transfer to NOD male mice. European Journal of Immunology, 22: 2387-2393. 